\title{
Grade I meningiomas with atypical characteristics: a worse prognosis
}

\author{
Meningiomas grau I com características atípicas: um pior prognóstico \\ Débora S. Marcos¹, Manoel A. Paiva Neto², Pedro Góes², Celina T. F. Oshimaํ, Marcelo S. Silva', João N. Stávale
}

\begin{abstract}
The study reviewed the histology of cases of grade I meningiomas with spontaneous necrosis, grade I without necrosis and grade II meningiomas, to evaluate the histological and immunohistochemical factors of the patients' prognosis, while correlating the clinicopathological features with the clinical follow-up of the patients. A review of 47 cases from the Department of Pathology of UNIFESP was performed and the samples were submitted to immunohistochemical examination with the p53 protein, Ki-67 cell proliferation factor and progesterone receptor markers. A greater expression was found in the progression of several degrees of aggressiveness for p53 and $\mathrm{Ki}-67$, and a higher frequency of progesterone receptors in the lower degrees. The group of grade I meningiomas with spontaneous necrosis showed histological and immunohistochemical indexes that approximate those of the grade II meningioma. This suggests a worse prognosis for grade I meningiomas with necrosis.
\end{abstract}

Keywords: meningioma; immunohistochemistry; prognosis; necrosis.

\section{RESUMO}

O objetivo do estudo foi realizar a revisão histológica de casos de meningiomas grau I com necrose espontânea, grau I sem necrose e grau Il para avaliar os fatores histológicos e imunohistoquímicos de prognóstico dos pacientes, correlacionando informações no âmbito clínicopatológico com o seguimento clínico dos pacientes. Foi realizada revisão de 47 casos do Departamento de Patologia da UNIFESP e as amostras foram submetidas a exame imunohistoquímico com os marcadores proteína p53, fator de proliferação celular Ki-67 e receptor de progesterona. Verificou-se maior expressão na progressão dos diversos graus de agressividade para p53 e Ki-67 e maior frequência de receptores de progesterona nos menores graus. O grupo dos meningiomas grau I com necrose espontânea apresentou índices histológicos e imuno-histoquímicos que se aproximam dos meningiomas grau II. Isto sugere um pior prognóstico dos meningiomas grau I com necrose.

Palavras-chave: meningioma; imuno-histoquímica; prognóstico; necrose.

Meningiomas comprise up to $36 \%$ of all primary intracranial neoplasms and the annual incidence of tumors corresponds to 10.5/100,000 in women and 4.8/100,000 in men. These are classified by the WHO into benign (grade I), atypical (grade II) or malignant/anaplastic (grade III), according to the histological characteristics observed. The lesions considered atypical are those that present an intermediate grade between benign and malignant variants, with the presence of four or more mitoses, or at least three of the histological characteristics close to anaplasia, such as hypercellularity, spontaneous focal necrosis, increased cytoplasm and prominent nucleoli, small-cell formation and sheeting architecture. Another diagnostic criterion recently introduced by the WHO is brain invasion ${ }^{1}$. Few studies refer to the presence of spontaneous necrosis in meningiomas with histological characteristics of grade I. Sun et al. $^{2}$ conducted the first study to identify spontaneous necrosis as a predictor of radioresistance. This finding is consistent with an oncology article ${ }^{3}$, in which cells in hypoxic regions demonstrate resistance to radiotherapy and chemotherapy.

For a histological and prognostic definition of the lesion, it is often necessary to use immunohistochemical techniques ${ }^{4}$. It is known that negativity for progesterone receptors may mean more aggressive tumor characteristics ${ }^{5}$, a positivity of Ki-67 factor reflects a proliferative capacity of the tumor ${ }^{6}$ and the p53 protein participates in the mechanisms of maintenance of DNA integrity but, when mutated, it is associated with several degrees of neoplastic behavior?

${ }^{1}$ Universidade Federal de São Paulo, Faculdade Paulista de Medicina, Departamento de Patologia, São Paulo SP, Brasil;

${ }^{2}$ Universidade Federal de São Paulo, Faculdade Paulista de Medicina, Departamento de Neurocirurgia, São Paulo SP, Brasil.

Correspondence: Débora Salles Marcos; Departamento de Patologia da UNIFESP; Rua Botucatu, 740 / Lemos Torres Building; $04021-001$ São Paulo SP, Brasil; debsalles@ig.com.br

Conflict of interest: There is no conflict of interest to declare.

Received 24 April 2018; Accepted 16 August 2018. 
The study reviewed the histology of cases of grade I and grade II meningiomas with spontaneous necrosis to evaluate the histological and immunohistochemical factors of the patients prognosis, evaluate spontaneous necrosis in grade I meningiomas and correlate this with their prognosis, while correlating information on the clinicopathological features with the clinical follow-up of the patients.

\section{METHODS}

\section{Casuistry}

This was a retrospective study in which the material used comprised 47 brain biopsies from patients with grade I meningiomas with spontaneous necrosis, grade I meningiomas without necrosis for comparison, and grade II meningiomas, selected from a total of 346 cases of meningiomas from the Department of Pathology of UNIFESP, during the period 2001 to 2014. The Research Ethics Committee of the Federal University of São Paulo approved the study.

\section{Histological and immunohistochemical review}

The histological sections were obtained from the paraffin blocks, a diagnosis was made and a representative block was selected. After being submitted to the hematoxylin-eosin staining process, these sections were analyzed, taking into account the criteria corresponding to each histological grade. All sections were submitted to immunohistochemical examination of p53, Ki-67 and progesterone receptor antibodies using the protocol recommended by UNIFESP. The sources and dilutions are shown in Table 1. We used a positive control breast tissue, from which six slides were cut and two different dilutions of the antibody were tested (1:50, 1:100) to check for a better result. Two observers analyzed each case, taking into account the strong expression of the markers used, and the percentage of positivity was calculated. The area with the highest proliferation index of each slide was identified, and the number of positive nuclei in 10 consecutive large-growth fields was calculated. For the Ki-67 marker 1,000 cells were counted with a squared eyepiece.

\section{Statistical analysis}

The statistical program used the values obtained for each case through microscopic analysis. The Kruskal-Wallis test was used to assess the level of significance, where a

Table 1. Antibodies and dilutions.

\begin{tabular}{lccc}
\hline Antibody & Clone & Source & Dilution \\
\hline p53 & DO-7 & DAKO & Flex system \\
Ki-67 & MIB-1 & DAKO & $01: 30$ \\
PR & 1A6 & Novocastra & $01: 50$ \\
\hline
\end{tabular}

PR: progesterone receptor; Ki-67: an antigen marker of cell proliferation; p53: protein expression. Material used in the study methodology. value equal to or less than 0.05 was considered significant and indicated that there was a greater possibility of difference between groups and a value greater than 0.05 was considered nonsignificant.

\section{RESULTS}

The average age of the patients was 53.7 years, the minimum age was 31 and the maximum was 76 years. We obtained clinical follow-up information on 22 patients. Of the grade II meningioma group, three individuals had tumor recurrence and were reoperated upon in periods ranging from one to four years for each case. Among the 15 cases of grade I meningiomas with necrosis, clinical follow-up information was obtained for 11 individuals. Of these, eight patients had a recurrence after surgical resection; two of them were submitted to radiotherapy and one was reoperated upon. The follow-up of all individuals showed no tumor growth after these processes.

Two patients with tumor transformation were described, one progressing from atypical to rhabdoid and the other from meningothelial to atypical. Five patients underwent treatment with radiotherapy, and there was follow-up of the 18 patients over varying periods of 2-16 years. Among the tumor subtypes, there were transitional, meningothelial, fibroblastic, angioblastic and atypical meningiomas. Regarding the location of the tumors, we found meningiomas on the convexity, in the olfactory gutter, parasagittal, brain sickle, sphenoid wing, foramen magnum, retroclival, extra-axial, intraorbital, intraventricular, sphenorbital, tuberculum, falcine, parafalcine and third ventricle.

\section{Immunohistochemistry}

The results found in immunohistochemistry are shown in Table 2. The Kruskal-Wallis test was used to obtain $p$-values for each group of different immunohistochemical markers. The p53 protein group had a nonsignificant $p$ value of 0.1415 . The Ki-67 and progesterone receptor groups showed values of 0.0165 and 0.0419 , respectively, both being considered significant.

Table 2. Clinical information and results

\begin{tabular}{lccc}
\hline Variable & GIWN & GI & GII \\
\hline $\begin{array}{lcc}\text { Gender } \\
\text { Male }\end{array}$ & $2(13.3 \%)$ & $7(46.6 \%)$ & $7(41.1 \%)$ \\
\hline Female & $13(86.6 \%)$ & $8(53.3 \%)$ & $10(58.8 \%)$ \\
Age & & & \\
$<40$ & $1(6.6 \%)$ & $5(33.3 \%)$ & 0 \\
$40-60$ & $10(66.6 \%)$ & $6(40.0 \%)$ & $10(58.8 \%)$ \\
$>60$ & $4(26.6 \%)$ & $4(26.6 \%)$ & $7(41.1 \%)$ \\
Immunoexpression average & & \\
\hline p53 & $15 \%$ & $30.4 \%$ & $44.8 \%$ \\
Ki-67 & $2.6 \%$ & $4 \%$ & $6.5 \%$ \\
PR & $75.3 \%$ & $45.6 \%$ & $35 \%$ \\
\hline
\end{tabular}

GIWN: grade I meningioma without necrosis. Gl: grade I meningioma with necrosis. Gll: grade II meningioma. 
The microscopic findings regarding the hematoxylineosin staining, Ki-67, progesterone receptor and p53 in the three groups can be seen in the Figure.

\section{DISCUSSION}

Meningiomas are the most frequent tumors, with incidences of $20 \%$ to $25 \%$ of grade II and I, and $6 \%$ of grade III $^{1}$. The present study showed a predominance in females, constituting $66 \%$ of the patients, while in males this rate was $34 \%$. This fact confirms the data found in most of the literature $^{8,9,10}$. The classification of an atypical meningioma is based on brain invasion, rate of mitosis and presence of at least three of five histological factors, among them spontaneous necrosis. Numerous studies have addressed this aspect, although a few analyze only the necrosis that occurs in grade I meningiomas as a prognostic factor. In the literature review of the present study, two studies were found that addressed this problem, Backer-Grøndahl et al. ${ }^{11}$ and Sun et al. ${ }^{2}$, the latter being the one that best analyzed the necrosis factor in the evolution of the meningiomas. In the present study, 15 sections of grade I meningiomas with necrosis were analyzed and it was observed that in six of them, the rate of cell proliferation was higher than the expected average for grade I meningiomas, while the expression of the progesterone was lower. The positivity for p53 ranged from $3 \%$ to $70 \%$. The evaluation of the cell proliferation index and the progesterone receptor approached the rates observed in atypical meningiomas. Of the nine remaining cases that had rates of cell proliferation within the expected range, the majority were found to have lower progesterone receptor indices. Among these patients, three presented with recurrence and very low p53 expression. The information obtained showed that one of the patients was subjected to radiotherapy and another was reoperated upon. Observing the two groups of grade I meningiomas, we found that the means of the markers p53 and Ki-67 were lower in the cases without necrosis, whereas the inverse occurred with the mean of the progesterone receptor marker. This suggests that the marker expression closer to that found in atypical meningiomas is observed in tumors with necrosis.

In their study, Cho et al. ${ }^{12}$ observed a p53 expression of $9.5 \%, 72.7 \%$ and $88.9 \%$ according to the three degrees of aggressiveness, and Telugu et al. ${ }^{13}$ obtained marking indices of $100 \%$ in malignant meningiomas and $83.3 \%$ in atypical

A

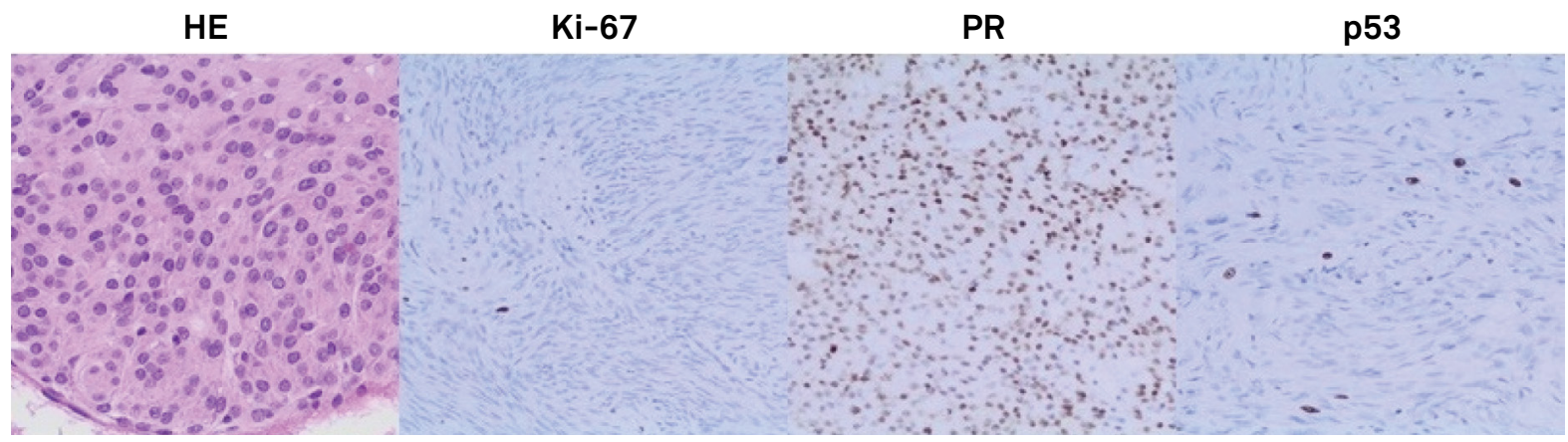

B
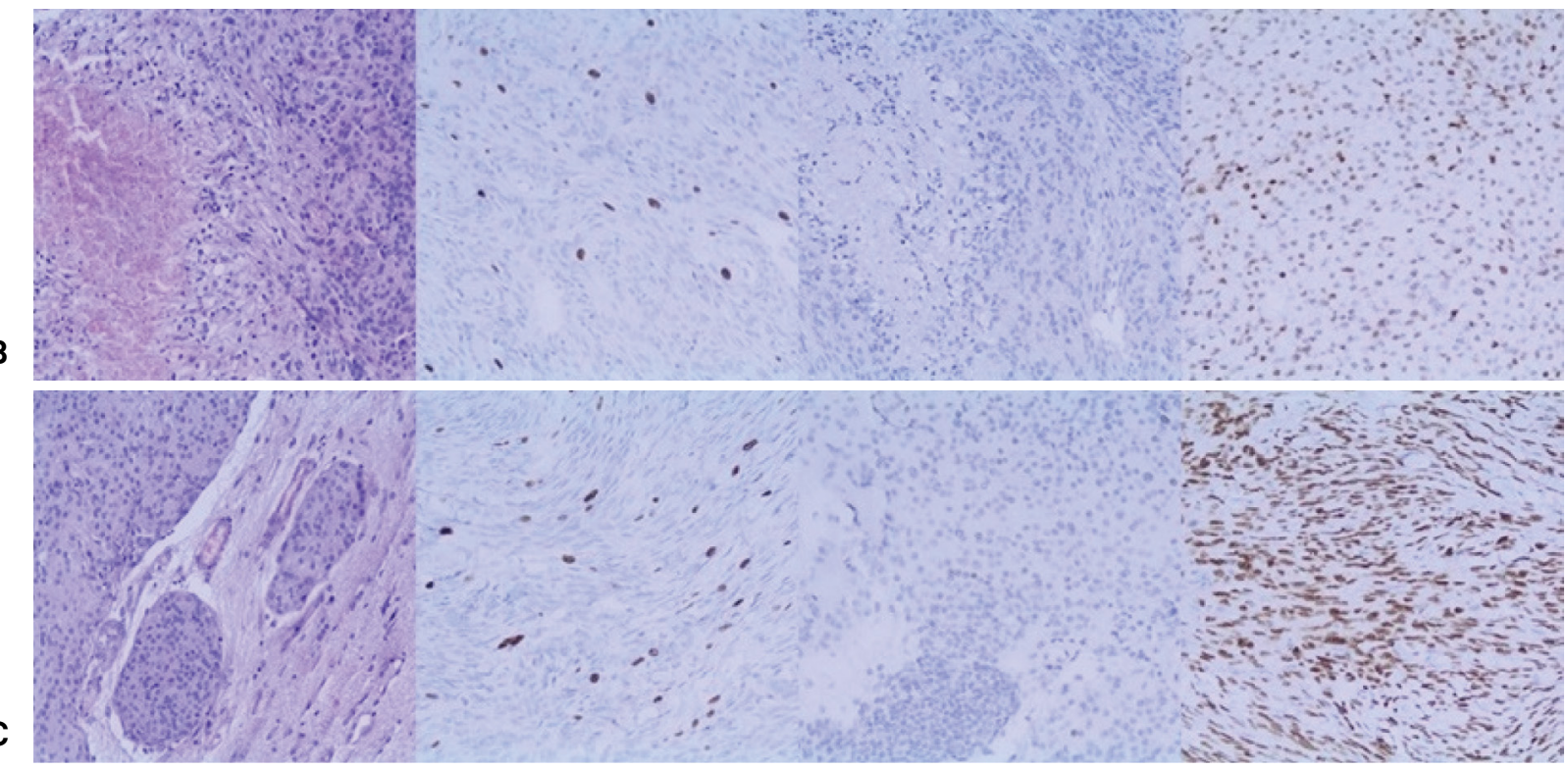

Figure. Photomicrograph showing immunopositivity for the progesterone receptor (PR), p53 and Ki67 labeling index for grade I meningioma without necrosis (A); grade I meningioma with necrosis (B); and grade II meningioma (C). 
meningiomas. Both results suggest higher p53 immunoreactivity in higher degrees of aggressiveness. The results found in this study, in turn, corroborate these reports and other authors, with a positive marker corresponding to $30.4 \%$ and $44.8 \%$ for grades I and II, respectively.

In relation to the cell proliferation factor, this study also showed greater expression of the marker in grade II tumors (4\% and 6.5\%, respectively for grades I and II), confirming most of the results found in other studies, such as Fakhrjou et al. ${ }^{14}$, who reported having found expressions of Ki-67 equivalent to $6 \%, 22 \%$ and $10 \%$ in grades I, II and III.

Concerning the frequency of progesterone receptors, the study by Kumar et al. ${ }^{15}$ showed expression of $83 \%$, 67\% and 30\% in grade I, grade II and grade III tumors, respectively, proving the relationship between receptor negativity in malignant cases. The same result was found by Shayanfar et al. ${ }^{5}$, in which there was positivity in 61/63 (96.8\%) of grade I, 2/10 (20\%) grade II and none $(0 \%)$ in grade III tumors. The results found in the present study also showed a higher frequency of progesterone receptors in the lowest degrees of aggressiveness, corresponding to $45.6 \%$ in the group of grade I tumors and $35 \%$ in grade II.

The study of prognostic markers in meningiomas, such as the cell proliferation index, immunoexpression of p53 and the progesterone receptor has been shown to be useful to corroborate grades of histological meningiomas. These markers have a greater importance when it comes to meningiomas that present with some more aggressive characteristics, but not enough to place them in a defined group, as is the case of the grade I meningiomas with necrosis. This group still requires more study, especially in the follow-up of patients, since one of the treatments proposed when the tumor is not completely surgically resected is radiotherapy, which, according to the work of Sun et al. ${ }^{2}$, has limited effectiveness. However, the question remains whether spontaneous necrosis is associated with tumor hypoxia and resistance to radiotherapy or whether it is a histological factor of greater aggressiveness independent of this treatment method.

In conclusion, in this study it was possible to perform a histological review of the biopsies and classify them into three different groups, including grade I meningiomas with spontaneous necrosis, grade I without necrosis and grade II. The group of grade I meningiomas with spontaneous necrosis showed histological and immunohistochemical indexes that approximate those of the grade II meningioma; however, they differ from those of grade I meningiomas without necrosis. This suggests a worse prognosis for grade I meningiomas with necrosis.

\section{ACKNOWLEDGMENTS}

We thank the Federal University of São Paulo and the Department of Pathology, which made this study possible, as well as the funding source CAPES.

\section{References}

1. Louis DN, Ohgaki H, Wiestler OD, Webster KC. Louis DN, Ohgaki H et al., editors. WHO classification of tumours of the central nervous system. 4th edition. Lyon: IARC; 2016.

2. Sun SQ, Cai C, Murphy RK, DeWees T, Dacey RG, Grubb RL et al. Management of atypical cranial meningiomas. Part 2: predictors of progression and the role of adjuvant radiation after subtotal resection. Neurosurgery. 2014 Oct;75(4):35663. https://doi.org/10.1227/NEU.0000000000000462

3. Muz B, Puente P, Azab F, Azab AK. The role of hypoxia in cancer progression, angiogenesis, metastasis, and resistance to therapy. Hypoxia (Auckl). 2015 Dec;3:83-92. https://doi.org/10.2147/HP.S93413

4. Perry A, Brat D, editors. Practical surgical neuropathology. In: Perry A, Brat D.,2nd edition. Philadelphia: Churchill Livingstone; 2010. Astrocytic and oligodendroglial tumors, p. 98-105.

5. Shayanfar N, Mashayekh M, Mohammadpour M. Expression of progestrone receptor and proliferative marker ki 67 in various grades of meningioma. Acta Med Iran. 2010 May-Jun;48(3):142-7.

6. Roser F, Samii M, Ostertag H, Bellinzona M. The Ki-67 proliferation antigen in meningiomas. Experience in 600 cases. Acta Neurochir (Wien). 2004 Jan;146(1):37-44. https://doi.org/10.1007/s00701-003-0173-4

7. Bénard J, Douc-Rasy S, Ahomadegbe JC. TP53 family members and human cancers. Hum Mutat. 2003 Mar;21(3):182-91. https://doi.org/10.1002/humu.10172

8. Backer-Grøndahl T, Moen BH, Torp SH. The histopathological spectrum of human meningiomas. Int J Clin Exp Pathol. 2012;5(3):231-42.
9. Pavelin S, Becic K, Forempoher G, Mrklic I, Pogorelic Z, Titlic M et al. Expression of $\mathrm{Ki}-67$ and $\mathrm{p} 53$ in meningiomas. Neoplasma. 2013;60(5):480-5. https://doi.org/10.4149/neo_2013_062

10. Jenkinson MD, Weber DC, Haylock BJ, Mallucci CL, Zakaria R, Javadpour M. Atypical meningoma: current management dilemmas and prospective clinical trials. J Neurooncol. 2015 Jan;121(1):1-7. https://doi.org/10.1007/s11060-014-1620-1

11. Backer-Grøndahl T, Moen BH, Sundstrøm SH, Torp SH. Histopathology and prognosis in human meningiomas. APMIS. 2014 Sep;122(9):856-66. https://doi.org/10.1111/apm.12248

12. Cho H, Ha SY, Park SH, Park K, Chae YS. Role of p53 gene mutation in tumor aggressiveness of intracranial meningiomas. J Korean Med Sci. 1999 Apr;14(2):199-205. https://doi.org/10.3346/jkms.1999.14.2.199

13. Telugu RB, Chowhan AK, Rukmangadha N, Patnayak R, Phaneendra BV, Prasad BC et al. Histopathological and immunohistochemical evaluation of meningiomas with reference to proliferative markers p53 and Ki-67. J Clin Diagn Res. 2016 Jan;10(1):EC15-9. https://doi.org/10.7860/JCDR/2016/15661.7117

14. Fakhrjou A, Meshkini A, Shadrvan S. Status of Ki-67, estrogen and progesterone receptors in various subtypes of intracranial meningiomas. Pak J Biol Sci. 2012 Jun;15(11):530-5. https://doi. org/10.3923/pjbs.2012.530.535

15. Kumar S, Kakkar A, Suri V, Kumar A, Bhagat U, Sharma MC et al. Evaluation of $1 p$ and $14 q$ status, MIB-1 labeling index and progesterone receptor immunoexpression in meningiomas: adjuncts to histopathological grading and predictors of aggressive behavior. Neurol India. 2014 Jul-Aug;62(4):376-82. https://doi.org/10.4103/0028-3886.141248 